Benefactive and substitutive applicatives in Bemba

Lutz Marten (School of Oriental and African Studies, University of London) and Nancy C. Kula (University of Essex)

Corresponding author: Lutz Marten,1m5@soas.ac.uk

Revised version 20 November 2012 


\title{
Benefactive and substitutive applicatives in Bemba
}

\begin{abstract}
Benefactive applicative constructions can encode a range of different meanings, including notably recipient, substitutive and plain benefactive readings, which are often distinguished in cross-linguistic studies. In Bantu languages, this distinction has not received much attention, in part because most Bantu languages do not formally distinguish between different readings of benefactive applicatives. In Bemba (Bantu M42, Zambia), by contrast, substitutive applicatives, where the action of the verb is performed by the agent instead of, on behalf of, or in place of someone else, are formally marked by applicative morphology in addition to a post-verbal clitic -kó, based on a grammaticalised locative demonstrative clitic. The paper provides a detailed discussion of the construction and proposes that the interpretation of substitutive applicatives results from the interaction of abstract applicative and locative semantics and depends on underlying metaphors of spatial and abstract location. Bemba benefactive applicatives thus provide an illustration of the complex function and interpretation of Bantu applicatives and locative markers more widely. The construction is interesting from a historical-comparative and typological perspective because of the particular grammaticalisation process from a locative source involved in the historical development of the construction, and because substitution is marked in addition to applicative marking.
\end{abstract}




\section{Benefactive and substitutive applicatives in Bemba ${ }^{1}$}

\section{Introduction}

Applicative constructions typically license the introduction of a new syntactic argument into the clause, which carries a particular semantic or thematic role, such as beneficiary, goal or location. Among the most wide-spread thematic roles expressed by applicative constructions is the beneficiary role, where typically an action is performed for the benefit of someone else. However, benefactive applicatives can express more specific meaning relations, among them in particular recipient, plain benefactive and substitutive meanings (cf. Kittilä 2005, Peterson 2007, Van Valin and LaPolla 1997: 384, Zúñiga 2010, Zúñiga and Kittilä 2010). Recipient constructions involve the transfer of an entity from the agent to the recipient, without specifying whether the recipient benefits from receiving the entity. In contrast, plain benefactives focus on the benefit of the beneficiary from the action denoted by the verb, irrespective of whether this action involves transfer or reception. Lastly, in

${ }^{1}$ We are grateful to Mary Dalrymple, Brent Henderson, Peter Sells, Nobuko Yoneda, Fernando Zúñiga and audiences at the LAGB Spring Meeting, University of Sheffield, April 2003, and the 11th LASU conference, Lusaka, May 2011, as well as to two anonymous reviewers for helpful comments and suggestions. Financial support is hereby gratefully acknowledged to the first-named author for fieldwork in Zambia in 1998 from the University of London Central Research Fund, and in 2005 from the AHRC (grant B/RG/AN8675/APN16312), and to the second-named author for fieldwork in Zambia in 2005 from the Netherlands Organisation for Scientific Research (NWO Grant number 275-70-006). 
substitutive readings the agent performs the action instead of, on behalf of or in place of the substituee. This reading does not involve transfer, and may or may not involve benefaction.

In analyses of Bantu languages, the distinction between recipient, plain and substitutive benefactives is often not drawn explicitly, even though it is frequently implied in descriptive grammars or the discussion of specific examples, especially of multiple applicatives (e.g. in Kimenyi 1995, Moshi 1998). The reason for the absence of more systematic treatments is that in most Bantu languages, there is no formal, morphosyntactic difference between these different types of benefactive applicatives, and so the distinction is not included in grammatical analyses of the construction.

In contrast to most Bantu languages, Bemba (Bantu M42, spoken in Zambia), does encode the difference between substitutive and other benefactives formally. Substitutive applicatives are formally expressed by the (historically) locative, class 17 post-verbal clitic -kó in conjunction with the applicative suffix -il/-el, as illustrated by the difference between the plain benefactive and the substitutive construction in (1): ${ }^{2}$

${ }^{2}$ Where no reference for examples is given, data are from the authors' fieldwork. Bemba data were collected during several research visits to Zambia from 1998 to 2011. We are grateful to our consultants Fenson Mwape, Rhoda Sambwa, and in particular Honoria Kula for detailed discussion of the data reported here. The following abbreviations are used in the glosses: $1,2,3, \ldots, 1 \mathrm{a}, 2 \mathrm{a}=$ noun class number; $1 / 2 \mathrm{SG} / \mathrm{PL}=1 \mathrm{st} / 2 \mathrm{nd}$ person singular/plural; $\mathrm{ACC}=$ accusative; $\mathrm{APPL}=$ applicative $; \mathrm{ART}=$ article; $\mathrm{ASP}=$ aspect $; \mathrm{BEN}=$ benefactive $; \mathrm{COND}=$ conditional; $\mathrm{DAT}=$ dative $; \mathrm{DEM}=$ demonstrative $; \mathrm{F}=$ feminine; $\mathrm{FOC}=$ focus $; \mathrm{FUT}=$ future tense; $\mathrm{FV}=$ final vowel; GEN = genitive; $\mathrm{HAB}=$ habitual tense; $\mathrm{LC}=$ locative clitic; $\mathrm{LOC}=$ locative $; \mathrm{NAR}=$ narrative tense $; \mathrm{NEG}=$ negation $; \mathrm{OM}=$ object marker; PASS 

(1) a. Ábá-icé
bá-ká-send-el-a
im-fúmu ubu-ta
2-children
SM2-FUT-carry-APPL-FV 9-chief
14-bow
'The children will carry the bow for (the benefit of) the chief'

[Bemba]

b. Ábá-icé

bá-ká-send-el-a=kó

2-children
SM2-FUT-carry-APPL-FV=LC17 im-fúmu ubu-ta

9-chief 14-bow

'The children will carry the bow on behalf of (instead of) the chief'

The examples show that the plain benefactive reading (1a) and the substitutive benefactive reading (1b) are formally distinguished by the use of -kó. The locative clitic -kó retains its locative meaning in other contexts, and indeed in some instances, constructions like (1b) are ambiguous between a substitutive benefactive interpretation and locative interpretation, as we will show in detail below. The locative origin of the clitic also results in specific interaction between it and locative predicates used in applicative constructions.

Bemba substitutives are theoretically interesting because of the use of a historically locative morpheme for the expression of substitutive semantics and the underlying metaphorical conceptualisations of space. While the detailed aspects of the grammaticalisation process involved in the development of the construction are $=$ passive $; \mathrm{PAST}=$ past tense $; \mathrm{PL}=$ plural; $\mathrm{PRES}=$ present tense $; \mathrm{PROG}=$ progressive aspect; PFV = perfective aspect; REC.PAST1 = recent past/past of today tense; $\mathrm{REL}=$ relative; $\mathrm{REM} . \mathrm{PAST}=$ remote past tense; $\mathrm{SBJV}=$ subjunctive; $\mathrm{SM}=$ subject marker. High tone is marked by an acute accent, downstep by an exclamation mark, and low tone remains unmarked. 
specific to Bemba, the use of spatial metaphors for substitutive meanings is more common, in particular the extension of "doing something in someone's place" to "doing something for somebody, or instead of somebody". Typologically, the construction is interesting both in the context of other processes of locative grammaticalisation in Bantu, and in the context of substitutive marking crosslinguistically, where Bemba belongs to a set of languages in which substitutive applicatives are marked by two morphemes. In what follows, we will provide a detailed description of the form and function of the construction which will provide the basis of the semantic analysis of the interaction of metaphorical space, direction and substitution in Bemba substitutives developed in the second half of the paper.

The paper is organised as follows. Section 2 presents an overview of different thematic roles expressed by applicatives which have been proposed in the literature, with specific reference to those found in Bantu languages, while section 3 focuses specifically on benefactive applicatives, and previous analyses in particular of substitutives in Bantu. Section 4 discusses (other) applicative constructions in Bemba, to provide the background for the more in-depth discussion of Bemba substitutive applicatives in section 5. Section 6 looks in detail at the substitutive marker and former locative clitic -kó and its role in substitutive constructions. In section 7, we draw different points from the previous sections together and present our analysis of the form, function and interpretation of Bemba substitutives and the grammaticalisation processes behind it. In section 8 we introduce comparative and typological contexts of locative grammaticalisation and substitutive marking, and show how Bemba substitutives are positioned within these contexts. Finally, section 9 presents the conclusions of the paper and perspectives for further research. 


\section{Thematic roles in applicatives}

A long research tradition has identified a range of thematic roles relevant for the analysis of applicative constructions, often based on evidence from Bantu languages (e.g. Baker 1989, Bresnan and Kanerva 1989, Grimshaw 1992, Jackendoff 1990, Mchombo 2004, Ngonyani and Githinji 2006). Among them are beneficiary, maleficiary, goal, experiencer, recipient, location, instrument, direction/goal, patient/theme, circumstantial or reason/motive. The most common thematic roles noted in Bantu are illustrated by the following examples:

Beneficiary

$\begin{array}{llll}\text { (2) Bo-Lungu ba-apeh-el-a } & \text { ba-eñi } & \text { li-tapi } & \text { [Lozi] } \\ \text { 2a-Lungu } & \text { SM2-cook-APPL-FV } & \text { 2-guests } & \text { 10-fish }\end{array}$

'Mr Lungu is cooking fish for the guests' (Marten et al. 2007: 313)

Location

(3) A-lēnje a-ku-pá-lúk-ir-á mí-kêka [Chewa]

2-hunters SM2-PRES-OM16-weave-APPL-FV 4-mats

pa-m-chēnga

16-3-sand

'The hunters are weaving mats on it, the beach' (Alsina \& Mchombo 1993: 42) 
Direction/Goal

(4) Waziri a-li-anguk-i-a chini [Swahili] minister SM1-PAST-fall-APPL-FV down

'The minister fell down/downwards' (Abdulaziz 1996: 32)

Motive/reason (circumstantial)

(5) Babá v-aká-úráy-ír-á

munhu marí [Shona]

1a.father SM2a-REM.PAST-kill-APPL-FV person money

'Father killed a person for money' (Harford 1993: 95)

Instrument

(6) Ya-ku-dumul-il-a sigi mage [Kagulu]

SM1-PRES-cut-APPL-FV 9.rope 14.knife

'S/he is cutting the rope with a knife' (Petzell 2008: 134)

Recipient

(7) Kuku a-ku-va-pelek-el-a $\quad$ va-jukulu $\quad$ [Ngoni]

1.grandpa SM1-PRES-OM2-send-APPL-FV 2-grandchild

v-aki chi-viga

2-his 7-pot

'Grandpa is taking the pot to his grandchildren' (Ngonyani \& Githinji 2006: 34) 
Possessor

(8) Tadala a-na-thyol-er-a

mw-ana ndodo

[Chewa]

Tadala SM1-PAST-break-APPL-FV 1-child 9.stick

'Tadala broke the child's stick' (or 'Tadala broke a stick for the child')

(Simango 2007: 929)

Theme
(9) Bw Msa a-na-chez-e-a $\quad$ karatasi z-a $\quad$ [Swahili]
Mr Msa SM1-PRES-play-APPL-FV 10.pages 10-GEN
ki-tabu ch-ake
7-book 7-his

'Bw Msa was playing with the pages of his book' (Abdulla 1960: 19)

The examples provide an overview of the different thematic roles assumed by applied objects of Bantu applicative constructions. Schadeberg (2003: 74) proposes a more concise set of three basic semantic/thematic roles of Bantu applied objects: “(i) beneficiary, (ii) place and - by extension - time, cause and reason, and (iii) instrument", corresponding to examples (2) to (6), above. He also notes that typically the applied object assumes the role of the primary object, and that often the added expression is coded as providing essential new information (see also Marten 2002, 2003 on the pragmatics of applicative constructions). Recipient applicatives in Bantu, as in (7), have been noted by Ngonyani and Githinji (2006), and the use of 
applicatives in the expression of possession, as in (8), for example, by Simango (2007). The use of an applied object to express a theme semantic role (9) has not been discussed in the literature, and the example might be regarded as an instance of instrument applicative; nothing depends on it for the present argument.

As the examples in (2) to (9) show, the different thematic interpretations of the applicative construction are all encoded by the same applicative morpheme, a variation of the typical Bantu applicative suffix -IL-, ${ }^{3}$ reconstructed in Proto-Bantu as *-id- (Meeussen 1967: 92; Good 2005: 6). While cross-linguistically, some languages employ formally different morphemes for the expression of different thematic roles, ${ }^{4}$ in Bantu there is typically no morphological variation in the marking of applicatives. The main exceptions to this are related to instruments (cf. Dammann 1961). In Bushong (Vansina 1959) and different north-east Bantu languages (Wald 1998), for example, instruments are coded on the verb by causative morphology, and in Duala (Ittmann 1939) and Bankon (Spellenberg 1922), comitative and instrument applicative semantics is expressed by the reciprocal/associative marker -an-. Furthermore, constructions with a post-verbal locative clitic, similar to the locative marker used in Bemba substitutive applicative constructions, found in some northeastern Bantu languages such as Bukusu (Peterson 2007: 12-14, but see Dierks 2010:

\footnotetext{
${ }^{3}$ The notation expresses that the vowel of the suffix is often subject to vowel harmony (typically /e/ vs. /i/), and the consonant subject to nasal harmony (/1/ vs. /n/). ${ }^{4}$ See, for example, the discussion of Hakha Lai, a Tibeto-Burman language spoken in Burma, in Peterson (2007: 41) where each different applicative reading (benefactive/malefactive, additional benefactive, comitative, malefactive/allative, prioritive, relinquitive or instrumental) is expressed by a different morpheme.
} 
62-68) or Kinyarwanda (Kimenyi 1995, Zeller and Ngoboka 2006) are sometimes analysed as locative applicatives, and we will return to these examples in section 8 .

The use of the thematic roles illustrated in the examples above in part captures semantic generalisations - showing the range of meanings associated with the applicative construction - but also morphosyntactic and comparative ones, for example, that instrumental applicative constructions are not possible in Shona (Harford 1993). The interaction of thematic roles with morphosyntactic processes such as passivisation and extraction has also given rise to the establishment of thematic hierarchies aimed at explaining the morphosyntactic behaviour of different applied objects, such as the comparatively extensive hierarchy proposed in Mchombo (2004: 129) (cf. also Ngonyani and Githinji 2006 for a summary of thematic hierarchies):

(10) Ag $>$ Ben $>$ Goal $/$ Exp $>$ Inst $>$ Pat $/$ Theme $>$ Loc $>$ Malefactive $>$ Circumstantial

In contrast, recent work on Bantu applicative constructions in the Minimalist Program does not adopt specific thematic roles as part of morphosyntactic explanation, even though the existence of thematic relations for the licensing of arguments is maintained. For example, in the analysis of Bantu applicatives proposed by Pylkkänen (2008: 17), where typical Bantu ("high") applicatives are analysed as a relation between an individual (the argument of the applied object) and the event denoted by the verb, a single semantic function is assumed which collapses more thematically specific functions which are not spelled out in detail:

(11) $\lambda x \lambda e \operatorname{Appl}(e, x)$ (collapsing $A p p L_{B e n}, A p p L_{\text {Instr }}, A p p L_{L o c}$, etc.) 
However, subsequent work has proposed a relation between "high" and "low" applicative structures and the difference between symmetric and asymmetric double object constructions in Bantu. This difference is partly related to thematic roles, in that, for example, in Kinyarwanda benefactive applicatives are symmetric, but locative applicatives are asymmetric. Thematic differences between different applicative constructions receive from this perspective a formal analysis in terms of different underlying syntactic structures. Applicatives which establish a relation between an event and an individual are analysed as high applicatives, but those which establish a relation between two individuals (e.g. the applied object and a theme object) or between an individual and a location are analysed as low applicatives (cf. Henderson 2011, Jeong 2006, McGinnis 2001). We will briefly return to this idea in section 7 with respect to substitutive applicatives.

What all these approaches share is that they are not centrally concerned with specific semantic interpretations of applicative constructions, which depend on the lexical semantics of the predicate or on the context in which the construction is used. In particular, this is true of different readings of benefactive applicatives, which are subsumed under one thematic role, despite the fact that substitutive applicatives can semantically be distinguished from other benefactive applicatives. In the following section we will illustrate the different readings available to Bantu benefactive applicative constructions, and provide examples of how these readings have been presented in the literature. In the subsequent sections, we will turn to Bemba, where the distinction between substitutive and other benefactive applicatives is marked morphologically. 


\section{Benefactive applicatives in Bantu}

Benefactive/malefactive applicative constructions are the most common types of applicatives, both in Bantu and cross-linguistically (Mchombo 2004: 80, Peterson 2007: 202, Schadeberg 2003: 74). However, as noted above, the term encompasses a number of different readings, and benefactive/malefactive applicatives ('doing something for/to X') may be interpreted in a number of ways (cf. Peterson 2007):

(12) Benefactive/malefactive applicatives can be interpreted as
a) contributing to $X$ 's well-being (plain, benefactive)
b) detracting from X's well-being (plain, malefactive)
c) involving something which ends up in the possession of $\mathrm{X}$ (recipient)
d) involving something which is directed towards X (direction/goal)
e) doing something instead of/on behalf of/in place of X (substitutive)

The availability of different readings for benefactives has been noted in the literature, and different distinctions have been proposed. Van Valin and LaPolla (1997: 384) propose three different senses of benefactives: plain, corresponding to the first two senses in (12), recipient, corresponding to (12c) and (12d), and deputative benefactives, corresponding to substitutive in (12e). Zúñiga (2010) introduces the term "surrogation" for readings of benefactives in which an action is carried out for or instead of someone and 'the beneficiaries' condition improves because they are relieved from having to carry out a given action themselves" (2010: 166), a reading 
which is often prominent in Bemba substitutives, as we will show below. Finally, Kittilä (2005) proposes a three-way distinction between recipients, (substitutive) benefactives, and recipient-benefactives. Based on a detailed, cross-linguistic investigation, he notes that while in some languages, one formal expression is used for all three readings, and in others all three readings are formally distinguished, there are several languages in which either recipients and recipient-benefactives are expressed with the same formal means, or benefactives and recipient-benefactives are expressed identically. The former, in Kittilä's terms, are recipient-prominent languages, while the latter are benefactive-prominent languages. The fact that recipient-benefactives are often encoded by the same forms as either recipients or benefactives shows that recipient-benefactives are similar to and may involve both reception and substitution.

For the present study we will adopt the descriptive categories in (12), and will concentrate in particular on the difference between substitutive and (other) benefactive applicatives, as this is the distinction expressed morphologically in Bemba. ${ }^{5}$ Kittilä (2005) notes that it is often not easy in practice to distinguish between

\footnotetext{
${ }^{5}$ There is also a particular problem with recipient readings, in that they are really only possible with verbs which have a (concrete) entity object, and are thus lexically more restricted than plain and substitutive benefactives. Furthermore, in Kittilä's examples, the majority of recipient readings are illustrated with "give" verbs, but these behave differently from applicatives in many Bantu languages, and would thus probably more profitably be investigated separately. This is in fact also a problem outside of Bantu (cf. Kittilä 2005: 271, Margetts and Austin 2007: 394/5).
} 
different readings, and we will show that benefactives are often semantically underspecified, receiving a particular interpretation only in context. ${ }^{6}$

The distinction between different readings of benefactive applicatives in Bantu has not been analysed systematically, presumably because, as noted above, different readings are typically not easily distinguishable morphosyntactically in most Bantu languages. However, in many descriptive grammars, different readings, in particular plain and substitutive readings, are mentioned, and often a discussion of different readings is found in the context of specific examples of applicatives. For example, Doke (1931: 131) notes that in Zulu benefactive applicatives "indicate the action when applied on behalf of or with regard to some object", identifying both substitutive ("on behalf of") and plain benefactive or direction/goal ("with regard to") readings. Similarly, Cammenga (2002: 387) notes that in Ekegusii "the meaning [of the applicative] may be translated as 'for, for the benefit of', or 'on behalf of'", and Seidel (2008: 232) gives a substitutive reading as the main meaning of the benefactive applicative construction in Yeyi: "the semantic core [of the applicative] can be characterized with the formula 'do something on behalf of somebody else'. Typically the applicative adds the semantic role of a benefactive". Often an indication of the possibility of a substitutive reading is also found in alternative translations given for examples of applicative constructions. For example, Abe (2011) translates the benefactive reading of the Inner Mbugu example in (13) as 'for/instead of', and Mchombo (2004) the Chichewa example in (14) as 'to/for':

\footnotetext{
${ }^{6}$ In this context it is interesting that Peterson (2007: 17) notes that “... possibly a substitutive reading is a subtlety for benefactive applicatives universally under appropriate circumstances", thus pointing out the context-dependent nature of substitutive readings.
} 
(13) Ú-kú-sáa-Pántu

ņ-ne-ku-Pántú-í-a

[Mbugu]

SM2SG-COND-NEG-cook SM1SG-FUT-OM2SG-cook-APPL-FV

lenu

tomorrow

'If you don't cook, I will cook for/instead of you tomorrow' (Abe 2011: 6)

\section{(14) Kalulú a-na-lémb-él-á}

\section{chi-tsílu kálata}

[Chewa]

1a.hare SM1-PAST-write-APPL-FV 7-fool 9.1etter

'The hare wrote the fool a letter = the hare wrote a letter to/for the fool'

(Mchombo 2004: 86)

Differences between different readings of benefactives are particularly apparent in examples with double applicatives or two benefactive arguments. Thus, for example, Kimenyi (1995) distinguishes three benefactive readings in Kinyarwanda as dative (corresponding to our plain benefactive), benefactive (corresponding to our substitutive benefactive) and possessive (15a), and analyses (15b) as including a beneficiary (umugabo) and a dative (abáana) argument:

\footnotetext{
(15) a. Umu-gabo

a-ra-som-er-a

umu-goré igi-tabo [Rwanda]

1-man

SM1-PRES-read-APPL-FV 1-woman 7-book

'The man is reading a book to the woman' (dative)

'The man is reading a book for the woman' (benefactive)

'The man is reading the woman's book' (possessive)
} 
b. Umu-goré

a-ra-som-er-er-a

1-woman umu-gabo abá-ana

1-man 2-children

igi-tabo

7-book

'The woman is reading the book to the children for the man' (dat+ben)

(Kimenyi 1995)

Similarly, Moshi (1998: 138/9) distinguishes between beneficiary (our substitutive benefactive) and recipient (our recipient benefactive) in the Chaga example in (16):

(16) Mangí n-á-lá-wé-í-á ḿká máná nyáma [Chaga]

chief FOC-SM1-PAST-slice-APPL-FV wife child meat

kíshú kílrí-nyi

knife room-LOC

'The chief sliced for the child for the wife the meat with a knife in the room.'

(Moshi 1998: 139)

On the distinction between the two roles, Moshi comments that the "recipient and the beneficiary can only be distinguished contextually. The intended meaning in this particular example takes the NP máá 'wife' as the beneficiary and máná 'child' as the recipient. That is, the child is the expected recipient of the meat which the chief cut on behalf of the wife" (1998: 139).

The context dependence of the interpretation of benefactive applicatives pointed out by Moshi with respect to Chaga can be illustrated when the wider context in 
which benefactives occur is taken into account, as in the following passage from Swahili:

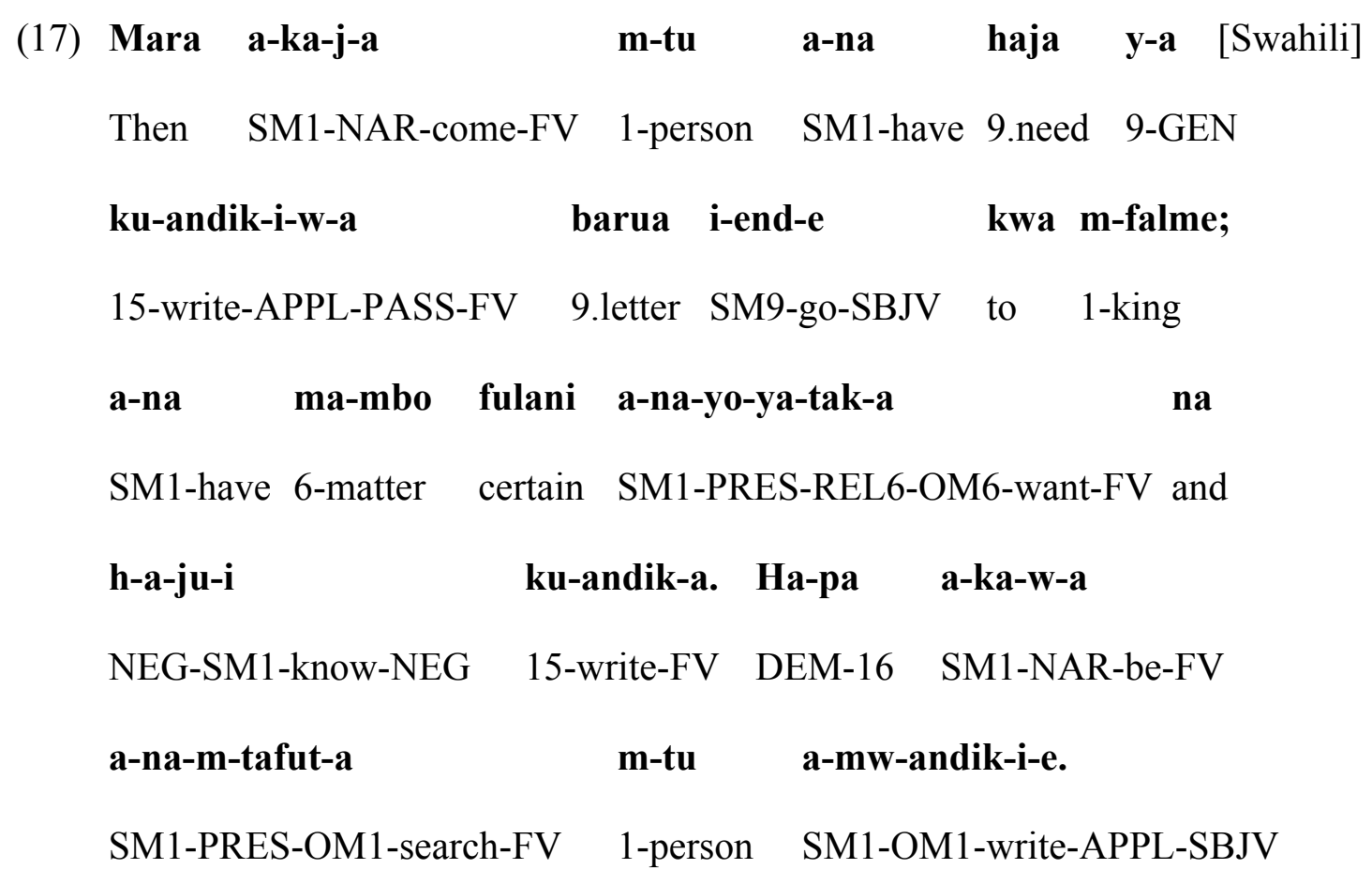

'And then arrived a man who needed a letter written for him to go to the king; he had a certain matter he wanted, and he didn't know how to write. Here then he was looking for a person to write for him.' (Kibao 1975: 23)

The two applicative forms in the example, kuandikiwa, 'to be written to/for', and amwandikie, 's/he should write to/for her/him' are ambiguous on their own between plain, recipient and substitutive benefactive readings. However, in the context it is clear that the intended recipient of the letter is the king, rather than the referent of the applied object (the man who had arrived), and so the recipient reading is unavailable. Furthermore, since the agent himself cannot write, he is looking for someone to write the letter for him, or in his place. The reading of the applicatives in this context is thus substitutive as well as benefactive since the protagonist benefits from having his letter 
written for him. The meaning of the applicative verbs in the passage thus includes benefaction as well as substitution, but this is not marked on the actual verb forms.

The examples discussed in this section show that in several Bantu languages, different readings of benefactives can be distinguished, and that, in particular, a difference between benefaction ("for") and substitution ("instead of") is often identified. Furthermore, even though this difference is not formally marked in any of the languages discussed in this section, the intended reading is often clear from the context, as example (17) from Swahili has shown. However, we will show in the following sections that in Bemba, not only can substitutive applicatives be distinguished from other benefactive readings on semantic grounds, but they are also explicitly morphologically marked.

\section{Applicatives in Bemba}

In this section we provide an overview of applicatives in Bemba, concentrating on the different thematic roles the construction expresses. We will reserve the discussion of substitutive applicatives for section 5, and will here focus on plain benefactives, malefactives, and recipient benefactives, as well as locative/directional, instrumental, motive/reason and lexicalised applicatives.

Bemba applicatives are formed with an applicative suffix -il, which is subject to vowel and nasal harmony, as well as spirantization. Bemba applicatives give rise to a range of different semantic readings, and the thematic properties of the construction conform in many respects to the characteristics of Bantu applicatives outlined in section 2. On the other hand, there are a number of qualities which do not readily fall 
out of general Bantu properties. The following examples illustrate the semantic roles that can be expressed by the applicative construction in Bemba (cf. Hoch n.d., Robertson 1904, Sadler 1964, Sambeek 1955, Sims 1959). ${ }^{7}$

The first set of examples (18-20) illustrates different non-substitutive benefactive readings: plain benefactive, plain malefactive, and recipient benefactive (we will discuss substitutives in detail in section 5).

Benefactive (plain benefactive)

(18)

a. N-a-lemb-eel-e

bá-mayó kalata

SM1SG-PAST-write-APPL-PFV 2-mother 9.letter

'I wrote my mother a letter' (Hoch n.d.: 261)

b. Bá-mayó bá-á-'ípík-il-a

ábá-ana ífy-umbu

2-mother SM2-PAST-cook-APPL-FV 2-children 8-potatoes

'Mother has just cooked potatoes for the children'

Malefactive

(19) a. Tw-á-mú-lí-íl-á

SM1PL-PAST-OM1-eat-APPL-FV

'We have eaten from her/him (i.e. eaten her/his food)'

\footnotetext{
${ }^{7}$ Bemba data from the literature have been slightly adapted for consistency. All glosses are ours. All examples have been checked for accuracy with language consultants.
} 
b. Na-bá-nj-íb-il-a

PRES-SM2-OM1SG-steal-APPL-FV 11-hoe

'They have stolen my hoe' (Sambeek 1955: 86)

Recipient benefactive (direction, goal)

(20) a. U-n-túm-ín-é

SM2SG-OM1SG-send-APPL-SBJV

'Send me your son' (Sambeek 1955: 86)

b. N-á-mú-'lét-él-a

SM1SG-PAST-OM1-bring-APPL-FV

'I have brought him an orange' (Hoch n.d.: 259) mw-an-ó

1-child-Poss2SG

i-cungwa

5-orange c. N-ácí-shít-il-a

SM1SG-REC.PAST1-buy-APPL-FV 2-mother 3-medicine

'I bought medicine for my mother' (Sadler 1964: 270)

As noted above, different readings of benefactive applicatives are sometimes difficult to tell apart out of context, and often two readings may be present in one form. For example, all examples in (20) involve reception, but it is not quite so clear whether they also involve benefaction. As the Swahili example above has shown, often the context makes clear which reading is intended, and we will see below how different readings of substitutives can be distinguished. 
Locative and directional applicatives are illustrated in (21) and (22). Examples (21) and (22a) show the interaction between applicative morphology and locative complements, giving rise to location and direction interpretation, depending on the lexical semantics of the verb, while in $(22 b)$ the directional interpretation results purely from the verbal semantics.

Location

(21) a. Bá-ká-lemb-el-a

pa-í-tébulo

SM2-FUT-write-APPL-FV 16-9-table

'They will do the writing on the table'

b. N-déé-li-il-a

mu-mú-putulé

SM1SG-PROG-eat-APPL-FV 18-3-room

'I am eating in the room'

Direction

(22) a. U-ka-w-iil-a

pa-ngáandá

SM3-FUT-fall-APPL-FV 16-9.house

'It (the tree) will fall on the house' (Sadler 1964: 298)

b. Mutálé a-léé-'m-pílíbúk-íl-á

Mutale SM1-PROG-OM1SG-turn-APPL-FV

'Mutale is turning towards me' 
With location and direction applicatives, the locative phrase retains overt (class 1618) locative marking, irrespective of the presence of applicative morphology. Furthermore, with location applicatives - though not normally with directional applicatives - the use of applicative morphology is often optional, its use indicating focus on the locative complement. In (23a), without the applicative marker, the example has neutral focus and can be used as an answer to "What are you doing?". In contrast, in (23b) with the applicative marker it has narrow focus on the location, answering "Where are you eating?". The applicative thus focuses the locative phrase (Marten 2003: 217):

a. n-déé-ly-a

SM1SG-PRES-eat-FV mu-mú-putulé

18-3-room

'I am eating in the room' (neutral; as answer to: 'What are you doing?') b. n-déé-li-il-a

SM1SG-PRES-eat-APPL-FV

\section{mu-mú-putulé}

18-3-room

'I am eating in the room' (emphatic; as answer to: 'Where are you eating?')

The pragmatic aspect of locative applicatives (and instrument applicatives, as we will show below) highlights the role of information structure in Bantu applicatives, in addition to, or maybe even instead of, syntactic valency changing (Marten 2002, 2003), and this is also found with substitutive benefactives as shown further below.

In instrument applicatives, like in locative applicatives, applicative morphology places focus on the instrument, while the instrument phrase is marked by a 
preposition such as na both with applicative morphology on the verb (24a) and without (24b). Instrument applicatives are also often found in genitive constructions, where an applicative marker is sometimes required (24c), but sometimes optional (24d).

Instrument

a. Mutálé a-léé-'ípík-il-a

na supuni

Mutale SM1-PROG-cook-APPL-FV with 9.spoon

'Mutale is cooking with a spoon', 'Mutale is using the spoon to cook with'

b. Mutálé a-léé-'ípík-a

na supuni

Mutale SM1-PROG-cook-FV with 9.spoon

'Mutale is cooking with a spoon'

c. sópo y-a ku-cáp-íl-á

9.soap 9-GEN 15-wash-APPL-FV

'soap for laundering' (Sadler 1964: 273)

d. ama-tété y-a ku-luk(-il)-a umu-seke

6-reed 6-GEN 15-weave-APPL-FV 3-basket

'reeds to make a basket' (Sambeek 1955: 86)

Another frequent role expressed by Bemba applicatives is motive/reason, shown in the examples below: 
Motive/reason/why

(25) a. Mu-léé-uman-in-a

SM2PL-PROG-argue-APPL-FV what

'What are you quarrelling about?' (Sambeek 1955: 85)

b. Mutálé a-léé-'ípík-il-a

Mutale SM1-PROG-cook-APPL-FV 9-hunger

'Mutale is cooking for (because of) hunger'

c. *Mutálé a-léé-'ípík-il-a

Mutale SM1-PROG-cook-APPL-FV 9-chicken 9-hunger

Intd.: 'Mutale is cooking the chicken for (because of) hunger'

The motive/reason use in reason questions illustrated in $(25 \mathrm{a})$ is a very common use of applicatives in Bemba, where 'why' is normally expressed by applicative morphology plus a question word such as nshi 'what'. However, motive/reason applicatives are also found in assertions such as (25b). Example (25c) shows that in motive applicatives, only the "reason" argument is allowed, but not an additional theme argument, indicating that at least in these cases, applicatives are not "valencyincreasing", but rather "valency-changing", treating a new argument as object instead of the object of the corresponding base verb. ${ }^{8}$

\footnotetext{
${ }^{8}$ The construction slightly improves when the theme object is expressed by an object marker:
} 
A final use of applicatives in Bemba is in lexicalised contexts, for example with the adverb limó, 'beforehand, in advance', which requires an applicative verb form (26a), or in the expression for 'warm oneself in the sun' (26b), though not for 'warm oneself at the fire' (26c).

\section{Lexicalised uses}

a. N-déé-kw-eb-el-a

limó

SM1SG-PROG-OM2SG-tell-APPL-FV in_advance

'I am telling you beforehand' (Sims 1959: 129)

b. uk-ont-el-a

aká-suba

15-warm-APPL-FV 13-sun

'to warm oneself in the sun' (Sambeek 1955: 86)

c. uk-ont-a umu-lilo

15-warm-FV 3-fire

'to warm oneself at the fire' (Sambeek 1955: 86)

A detailed analysis of the different functions of Bemba applicatives is beyond the scope of this paper, and we will concentrate on benefactive applicatives in what

(i) ?Mutálé a-léé-fi-ípík-il-a in-sala

Mutale SM1-PROG-OM8-cook-APPL-FV 9-hunger

'Mutale is cooking them (e.g. the potatoes) because of hunger' 
follows. However, as e.g. Dammann (1961) notes, one basic underlying meaning of the applicative suffix can be seen to be related to direction: Physical direction in the case of directive applicatives, direction of the action towards another person in the case of benefactives, or direction of the attention of the hearer towards an instrument or a place. We will show below that this abstract notion of direction found in benefactives interacts with an abstract notion of location in substitutive applicatives, which are expressed by applicative morphology and a locative clitic. We turn to substitutive applicatives in the next section.

\section{Bemba substitutive applicatives}

This section presents a detailed description of substitutive applicatives in Bemba. The discussion begins with the difference between plain benefactives and substitutives, in terms of morphology and interpretation, and then turns to the semantic underspecification of the construction and the interaction with context in interpretation. We will show that substitutives are based on benefactives, and that substitutive readings do not arise with other, non-benefactive applicatives. A special class of applicatives are those based on verbs of movement and motion, and we will show the intricate interaction between those and substitutive interpretations. A final question addressed in this section is related to the syntactic behaviour of substitutives, which we show is identical to benefactives. 


\subsection{Morphological marking and interpretation}

Substitutive benefactive applicatives in Bemba are marked morphologically by the applicative marker -il and the post-verbal historical locative clitic -kó, as shown in the examples in (27): ${ }^{9}$

(27) a. N-da-ku-fund-íl-á=kó

SM1SG-HAB-OM2SG-teach-APPL-FV=LC17

'I teach instead of you' (Sadler 1964: 271)

b. Á-ká-'bá-téyánish-ish-a=kó

í-tébulo

SM1-FUT-OM2-prepare-APPL-FV=LC17 5-table

'He will set/prepare the table instead of them' (Sadler 1964: 271)

In both examples, the action of the verb is performed by the subject instead of the benefactive object. The example shows that substitutive applicatives can be formed from intransitive (or object-drop) verbs (27a) as well as from transitive verbs (27b). In both examples, the verb shows applicative morphology as well as the (former) locative clitic -kó.

The difference between plain and substitutive benefactive readings is further illustrated by the contrast between the following examples:

\footnotetext{
${ }^{9}$ In (27b) the applicative marker undergoes spirantization triggered by the preceding fricative.
} 
SM1SG-FUT-wash-APPL-FV Chali

'I'll bathe for Chali (because he is coming and I want to please him)'

(Sadler 1964: 272)

b. N-ka-samb-il-a

Chali úmu-ána

SM1SG-FUT-wash-APPL-FV Chali 1-child

'I'll bathe the child for Chali' (Sadler 1964: 270)

c. N-ka-samb-il-a=kó

SM1SG-FUT-wash-APPL-FV=LC17 Chali 1-child

'I'll bathe the child instead of Chali (bathing him)' (Sadler 1964: 271)

The verb -samba 'wash, bathe' can be used intransitively and transitively, and consequently, the corresponding applicative verb can combine with a beneficiary object such as Chali in (28a) or with a beneficiary (Chali) and a theme (úmuána) object in (28b). When the applicative verb is combined with the post-verbal clitic -kó, as in (28c), a substitutive reading results, in which the agent performs the action in place of the substituee object (at least under the reading given in the example). As (28c) shows, the substituting relation holds between the agent and the substituee object Chali. If the substitution relation is meant to hold between the two objects, it has to be expressed differently, for example by using the preposition ukùcila, 'instead of (lit. to surpass)', as in (29). This meaning cannot be expressed by substitutive applicatives. 
(29) N-ka-samb-a

úmu-ána úkú-cila Chali

SM1SG-FUT-wash-FV 1-child 15-surpass Chali

'I'll bathe the child instead of (bathing) Chali' (Sadler 1964: 272)

In most cases, the two participants involved in the substitution relation are quite clear, like in the examples discussed so far. However, while the relation always involves the agent, the role of the substituee is subject to pragmatic construal. Furthermore, both the applicative marker and -kó can express a range of different readings, and so the combination results in several possible interpretations. For example, out of context, (30) can express a number of readings:

(30) Bá-mayó bá-lée-ípík-íl-a=kó

2-mother SM2-PROG-cook-APPL-FV=LC17 1-guest behalf of s.o. else who was supposed to do it', 'Mother is cooking for the guest as a nice gesture', 'Mother is cooking for the guest there/at some location'

The four different readings identified in (30) result from the semantically underspecified nature of the two morphemes involved in substitutive applicatives. The first reading is the most natural one, in which the referent of the applied object (the guest) is the substituee. However, it is also possible that the substituee remains unexpressed, and inferable from the context, as in the second reading, where the guest assumes the role of (plain) beneficiary. The final two readings result from different meanings associated with -kó, which we will discuss in more detail below. The third reading involves the use of -kó as indirectness/politeness marker, for example, in a 
situation where the guest is very tired and nobody else is available to cook for her, and the mother cooks for her as a nice gesture. The final reading involves the (physical) locative sense of the locative marker -kó, referring to a specific location where the cooking takes place. In the last two readings, the guest is the beneficiary. In the following examples we will normally only give the intended reading, but it has to be kept in mind that the combination of applicative morphology and -kó out of context results in several different possible readings.

The ambiguity of benefactive/substitutive/locative readings is reduced when more lexical information is provided. In (31), for example, where an animate NP is part of the theme argument, which is expressed in addition to the applicative object, the respective semantic roles are more strictly assigned:

a. Bá-mayó bá-á-'ípík-íl-a

2-mother SM2-PAST-cook-APPL-FV

fy-a bá-ana

8-GEN 2-children

'Mother cooked the potatoes of the children for (the benefit of) Chongo'

b. Bá-mayó bá-á-'ípík-íl-a=kó

2-mother SM2-PAST-cook-APPL-FV=LC17 Chongo 8-potatoes

fy-a bá-ana

8-GEN 2-children

'Mother cooked the potatoes of the children for (instead of) Chongo' 
In the preferred reading of (31a), Chongo is a beneficiary argument, so the potatoes are being cooked for Chongo, instead of for the children, to whom they belong. In contrast, in (31b), Chongo is the substituee argument, and so the interpretation of the example is that Chongo was supposed to have cooked the children's potatoes (so that they should eat them), but now the mother has cooked them instead of Chongo, in her place (while the children remain the ones eating the potatoes in the end). Since there are three participants expressed in (31), the structure of the event is less subject to pragmatic enrichment than in the case of (30) with only two participants overtly encoded. A similar effect obtains in (32), where two object markers are combined. This is possible in Bemba if one of the object markers is a 1st person singular marker, or if both object markers are animate (cf. Marten et al. 2007, Marten and Kula 2012):

\section{(32) Mú-ká-'bá-mú-éb-él-é=kó}

SM2PL-FUT-OM2-OM1-tell-APPL-SBJV=LC17

'You should tell them for him/on his behalf'

In these cases, the interpretation is typically fixed, with the object marker closer to the verb assuming the substituee role.

The examples so far have shown that substitutive applicatives differ from plain and recipient benefactive applicatives in both morphology and interpretation. The central meaning of substitutives is the performance of the action of the verb by the agent instead of the substituee. However, benefaction appears to remain a semantic component of the interpretation. Typically, the meaning of substitutives implies both that the action is performed by the referent of the subject instead of the referent of the applied object, and also that the referent of the applied object benefits from this - 
often in the sense that the referent of the applied object was under some obligation, or supposed to do the action, and the referent of the subject relieves them from this obligation by performing the action in their place.

However, substitutive readings, like other benefactive readings, depend on the particular predicate and the context, and comprise of a range of interpretations. While the prototypical substitutive reading entails that the action is performed by the agent in place of, or instead of someone else, usually the referent of the applied object, more indirect relations are also possible. For example, in (33) the agent takes the place of the speaker (the referent of the applied object) to speak up for her, without necessarily speaking instead of her.

\section{(33) A-alí-n-sós-éel-e=kó}

SM1-REM.PAST-OM1SG-speak-APPL-PFV=LC17

'He spoke in my favour/defence' (cf. Sambeek 1955: 85)

Furthermore, substitutive meaning appears to be built on benefactive meaning. When -kó is combined with a malefactive applicative (cf. 19a, repeated here as 34a), the malefactive reading disappears $(34 b)$ :

\section{(34) a. Tw-á-mú-lí-íl-á}

SM1PL-PAST-OM1-eat-APPL-FV

'We have eaten from her/him (i.e. eaten her/his food)' 


\section{b. Tw-a-mu-li-il-a=kó}

\section{SM1PL-PAST-OM1-eat-APPL-FV=LC17}

'We have eaten instead of (*from) him/her'

While in (34a), the applied object is negatively affected by the action, the example in (34b) cannot mean 'we ate instead of him/her, and s/he suffered because of this'. The meaning in (34b) instead entails that the substituee's well-being is improved by the action, for example if the substituee was under a social obligation to eat, but was unable to do so, and so benefits from someone eating on her behalf. Substitutive applicatives are thus incompatible with malefactive readings, and typically imply a benefactive effect for the substituee.

The examples discussed show that Bemba substitutive applicatives are distinct construction types, combining a benefactive applicative structure with the former locative clitic -kó to result in a distinct substitutive interpretation.

Before turning to substitutive applicatives of movement predicates, we will show that the use of -kó with locative and instrument applicatives does not result in substitutive applicatives, as is expected given that we have shown that substitutive applicatives result from an interaction of benefactive and substitutive semantics. In locative applicatives, the locative clitic assumes its concrete, physical locative sense, following the overall locative sense of the construction:

(35) Ba-Rhoda bá-léé-cish-il-a(=kó)

2-Rhoda SM2-PROG-iron-APPL-FV(=LC17) 8-clothes

'Rhoda is ironing clothes in the house'

\section{ífy-akufwala mu-ngáanda}

18-9.house 
Note that the example involves the grammaticalised locative clitic, as the clitic does not agree with the class 18 locative phrase munganda. However, the meaning of the construction with -kó in (35) is the same as it would be without -kó - the focus on the location (indicated by italics) is a function of the applicative, not of the locative, as noted above. With instrument applicatives, the situation is slightly different, as there is no location and no substituee involved, and so the locative clitic cannot be readily interpreted in either the physical or the substitutive reading. As with locative applicatives, there is a difference between the non-applied verb (36a) and the applicative construction in (36b), in that the applicative places focus on the instrument. However, the use of -kó is only marginally acceptable, and if used, gives rise to a "surprise" reading (36c) (we will return to this reading in section 6).

(36) a. Mutálé a-léé-'ípík-a

Mutale SM1-PROG-cook-FV with 9.spoon

'Mutale is cooking with a spoon'

b. Mutálé a-léé-'ípík-íl-a

Mutale SM1-PROG-cook-APPL-FV with 9.spoon

c. ?Mutálé a-léé-'ípík-íl-a=kó

na supuni

Mutale SM1-PROG-cook-APPL-FV=LC17 with 9.spoon

Intd.: 'Mutale is (surprisingly) cooking with a spoon' 
The examples discussed in this section thus show that the interpretation of substitutive applicatives is a function of both benefactive applicative meaning and the specific substitutive meaning supplied by -kó. The substitutive marker -kó thus plays a distinct semantic role in substitutive constructions, but retains only a locative sense with non-benefactive applicatives. In the following section we show how this interaction works out with movement and motion predicates.

\subsection{Substitutive applicatives with movement predicates}

A specific context relevant for the understanding of substitutive applicatives is their interacation with verbs of movement or motion such as -pílíbuka 'turn', -bútúka 'run', or -tólóka 'jump'. With these predicates, applicative forms typically do not result in benefactive readings, but in directional interpretations, where applicative semantics interacts closely with the lexical meaning of the predicate. However, the addition of the locative clitic -kó results in substitutive readings, in what appears to be a coercion of the benefactive reading of the applicative. In the case of -tólóka, for example, the unextended verb means 'jump' (37a). However, in contrast to, for example, the corresponding English form, the verb can be used with an object such as bámayó in (37b), and in that case, the meaning changes to 'jump over'. The applicative verb form in (37c) does not result in a benefactive reading, but directs the action of the verb towards the applied object, so the meaning becomes 'jump onto'. However, when the locative clitic -kó is added, a substitutive reading results (37d). 
a. Mutálé a-léé-'tólók-á

Mutale SM1-PROG-jump-FV

'Mutale is jumping'

b. Ábá-icé bá-lée-tólók-a bá-mayó

2-children SM2-PROG-jump-FV 2-mother

'The children are jumping over the mother'

c. Ábá-icé bá-lée-tólók-el-a bá-mayó

2-children SM2-PROG-jump-APPL-FV 2-mother

'The children are jumping onto the mother'

\section{d. Ábá-icé bá-lée-tólók-el-a=kó bá-mayó}

2-children SM2-PROG-jump-APPL-FV=LC17 2-mother

'The children are jumping for/on behalf of the mother'

*'The children are jumping onto the mother'

Similar effects can be seen with the verb -bútúka 'run', even though with slightly different lexical semantics, and the following examples illustrate the interaction between the verbal semantics, applicative marking and the locative clitic -kó in more detail. When used without object and without applicative extension, -bútúka simply means 'run' (38a), and when used with an object, the meaning changes to 'run away (from X)' (38b). The effect of adding an applicative extension and an applied object, illustrated in (38c), is to reverse the direction of the running - it is now directed towards the object. A benefactive interpretation of the example is not possible. 
However, in (38d), when -kó is added, a substitutive reading results, which, as shown above, presupposes a benefactive interpretation of the applicative. Indeed, (38e) and (38f) show that -kó by itself does not give rise to a substitutive reading when combined with -bútúka either without or with the applicative extension. In both cases, the locative clitic receives its physical locative intepretation and denotes the place from where/towards which the running takes place, or, without the applicative extension, alternatively a partitive interpretation (38e) (discussed in more detail in section 6).

(38) a. Mutálé a-léé-'bútúk-á

Mutale SM1-PROG-run-FV

'Mutale is running'

b. Mutálé a-léé-m-bútúk-á

Mutale SM1-PROG-OM1SG-run-FV

'Mutale is running away from me'

c. Mutálé a-léé-mu-bútúk-íl-á

Mutale SM1-PROG-OM1-run-APPL-FV

'Mutale is running towards him/her'

*'Mutale is running for him/her’ 


\section{d. Mutálé a-léé-mu-bútúk-il-a=kó}

Mutale SM1-PROG-OM1-run-APPL-FV=LC17

'Mutale is running for/on behalf of him/her'

*'Mutale is running towards him/her'

e. Mutálé a-léé-'bútúk-a=kó

Mutale $\quad$ SM1-PROG-run-FV=LC17

'Mutale is running away from there/running a bit'

\section{f. Mutálé a-léé-'bútúk-il-a=kó}

Mutale SM1-PROG-run-APPL-FV=LC17

'Mutale is running towards there'

The examples show that substitutive applicatives result from an interaction of benefactive applicatives and the specific substitutive semantics supplied by the locative clitic -kó. In particular the contrast between (38d) and (38f) shows that it is not applicative semantics as such which combines with locative semantics, but that the applicative needs to be construed as benefactive. This is possible in (38d) since the class 1 object (expressed by the object marker -mu-), which in (38c) is interpreted as the endpoint of the runnig, can be interpreted as the applied object on whose behalf (and for whose benefit) the action is performed. Since no such possible substituee argument is available in (38f), the resulting interpretation is locative, not substitutive.

We conclude our discussion of the meaning and function of Bemba substitutive applicatives by noting that only the combination of the correct applicative semantics (benefactive) with the substitutive marker and historical locative clitic -kó results in 
the substitutive reading. In the following section, we look at structural properties of substitutive applicatives and point out parallels in the syntax of substitutives and plain benefactive applicatives.

\subsection{Structural similarities between substitutive applicatives and non-substitutive (plain) applicatives}

The preceding section has illustrated semantic differences between substitutive and other benefactive applicatives and how the difference between the two constructions is encoded morphologically. In this section we will show that syntactically substitutive applicatives are like other benefactive applicatives. Like in all benefactive applicatives in Bemba, only one additional object is licensed in substitutive applicatives, and this object assumes primary object characteristics (that is, Bemba is an "asymmetric" language). In contrast to, for example, languages like Kinyarwanda or Chaga, Bemba does not allow multiple applied objects:

\section{*Bá-mayó bá-léé-'ípík-íl-a=kó}

2-mother

\section{SM2-PROG-cook-APPL-FV=LC17}

Chongo

Chongo

\section{umw-éni}

1-guest

Intd.: 'The mother is cooking for the guest on behalf of Chongo'

The example shows that the overt expression of both a beneficiary and a substituee object at the same time is not possible. Even though -kó changes the interpretation of the benefactive constructions, the morpheme does not introduce a separate object in addition to the applied object introduced by the applicative morphology. Applicative 
constructions in Bemba thus license the introduction of at most one applied object, irrespective of the interpretation of that object. Furthermore, this object assumes primary object characteristics as shown below.

The most well-known syntactic properties of Bantu applicative constructions are related to the grammatical status of the applied object and the theme object, and languages are often said to have either symmetric (the two objects behave alike) or asymmetric (the two objects differ) applicative constructions (e.g. Bresnan and Moshi 1990, Ngonyani and Githinji 2006). Three syntactic tests associated with this distinction are word-order, passivisation and object marking, and both Bemba benefactive applicatives (see Marten et al. 2007: 292/3) and substitutive applicatives behave as asymmetric with respect to all three of them. With respect to word-order, the applied, substitutive object precedes the theme object (40a), and the opposite order is ungrammatical (40b):

a. Bá-mayó bá-á-'ípík-íl-a=kó

2-mother SM2-PAST-cook-APPL-FV=LC17 Chisanga 8-potatoes

'The mother has cooked potatoes on behalf of/instead of Chisanga'

\section{b. *Bá-mayó bá-á-'ípík-íl-a=kó}

2-mother SM2-PAST-cook-APPL-FV=LC17 8-potatoes Chisanga

Similarly, the applied object in substitutive applicatives can be promoted to subject in a corresponding passive construction, but the attempt to promote the theme object in passives leads to ungrammaticality. Bemba passives are only in some cases formed 
with the common Bantu passive marker -w-, and the standard expression of passive meaning involves a grammaticalised form of topicalisation with a passive marker ba-, based historically on an indefinite class 2 ('they') subject marker. In the examples below, the subject (or, in any case, the pre-verbal constituent) thus shows agreement with the "object" marker, while in the position otherwise reserved for subject markers, the reanalysed passive marker (and former class 2 subject marker) ba- is found. The main reason for analysing the construction as a passive, rather than as an instance of object topicalisation is that the agent can be expressed by a "by-phrase" introduced by kuli 'by' (see Kula and Marten 2010 for further discussion). Irrespective of the detailed analysis of Bemba passives, the examples show that the applied object can be fronted in ba-passives (41a), while this is not possible with the theme object (41b):

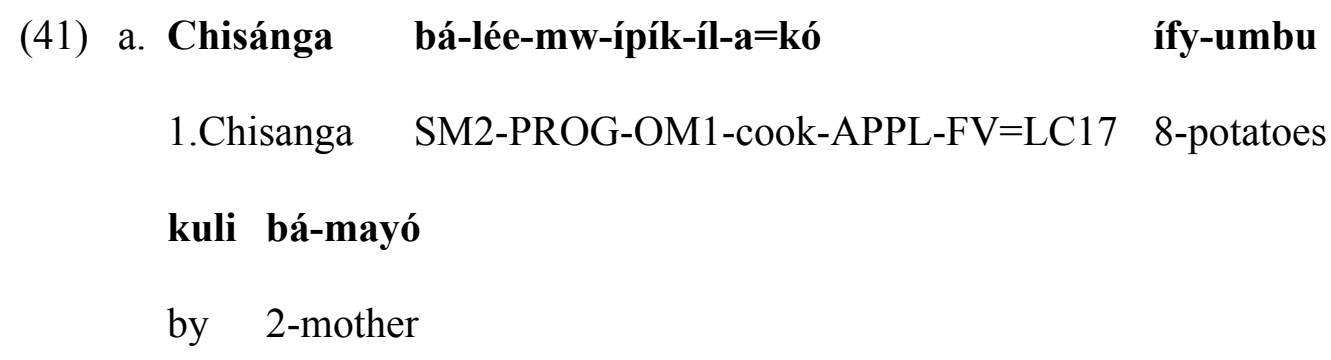

'Chisanga was cooked potatoes for/on behalf of by mother'

\author{
b. *In-kókó bá-léé-i-ípík-íl-a=kó \\ BanaPhiri \\ 9-chicken SM2-PROG-OM9-cook-APPL-FV=LC17 BanaPhiri

\section{kuli BanaNyerenda} \\ by BanaNyerenda \\ Intd.: 'The chicken was cooked for/on behalf of BanaPhiri by \\ BanaNyerenda'
}


Finally, and in line with the two previous results, object marking is only possible for the applied object, but not for the theme object. The applied object is object marked by the class 1 object marker -mu- in (42a), but the attempt to express the theme object by the class 8 object marker $-\mathbf{f i}-$ in $(42 b)$ renders the sentence ungrammatical:

(42) a. Bá-mayó bá-á-mu-ípík-íl-a=kó

ífy-umbu,

2-mother SM2-PAST-OM1-cook-APPL-FV=LC17 8-potatoes

\section{Chisánga}

Chisanga

'The mother has cooked potatoes for/on behalf of him, Chisanga'

b. *Ábá-ana bá-á-fi-ípík-íl-a=kó

Chisánga

2-children SM2-PAST-OM8-cook-APPL-FV=LC17 Chisanga

Intd.: 'The children have cooked them for/on behalf of Chisanga'

Substitutive applicatives are thus consistently asymmetric, exactly like nonsubstitutive benefactive applicatives. This confirms further the proposal made earlier, that substitutives are based on benefactives, to which -kó adds substitutive meaning.

In the following section we will look in more detail at this second morphological marker of substitutive applicatives, the post-verbal locative clitic -kó. 


\section{The locative marker $-k o ́$ and its use in substitutive applicatives}

The locative marker -kó plays a central role in the marking of substitutives in Bemba. In this section we provide a discussion of the form and function of -kó. We present the locative demonstrative paradigm of which -kó is part, and the use of locative clitics with nominal and verbal hosts. We then discuss in more detail different grammaticalised uses of -kó.

\subsection{Post-verbal locative clitics and the locative maker -kó}

The substitutive applicative marker -kó is historically a locative (class 17) marker, originating from a locative demonstrative. Like many Bantu languages, Bemba has three locative classes, denoting specific location (class 16), approximate location or direction (class 17), and interiority (class 18) (e.g. Hoch n.d.: 91). In addition, Bemba has a four-way demonstrative system with the different forms distinguishing near and far distance with respect to speaker and addressee. The form expressing nearness to the addressee is in addition used as anaphoric demonstrative for reference to already mentioned antecedents (Hoch n.d.: 127, Mann 1977: 26) (Table 1). 
Table 1. Bemba locative demonstrative series

\begin{tabular}{|l|l|l|l|l|l|}
\hline Class & Noun & Dem 1 & Dem 2 & Dem 3 & Dem 4 \\
& & very near & near to & near to & far from \\
& to speaker & speaker & addressee; & speaker \\
and & already & and \\
\hline 16 & $\begin{array}{l}\text { pamushi } \\
\text { 'at the village' }\end{array}$ & pano & apa & apó & palyá \\
\hline 17 & $\begin{array}{l}\text { kumushi } \\
\text { 'by the village' }\end{array}$ & kuno & uku & ukó & kulyá \\
\hline 18 & $\begin{array}{l}\text { mumushi } \\
\text { 'in the village' }\end{array}$ & muno & umu & umó & mulyá \\
\hline
\end{tabular}

The anaphoric forms (Demonstrative 3) modifying a locative noun are illustrated for the three locative classes in (43):

(43) a. pa-ngáanda apó

16-9.house DEM16

'at that house'

b. ku-ngáanda ukó

17-9.house DEM17

'by/to that house' 
c. mu-ngáanda umó

18-9.house DEM18

'in that house'

When used after verbs, the initial vowel of the demonstrative forms may fuse with the final vowel of the verb form, resulting in /o:/ for class 17 and 18 demonstratives when they follow verbs ending in -a.

(44) a. Poos-áápó!

$(<$ poosa apó $)$

throw_away-DEM16

'Throw (it) there (specific)!'

b. Poos-óókó!

$(<$ poosa ukó)

throw_away-DEM17

'Throw (it) there!'

c. Poos-óómó!

(< poosa umó)

throw_away-DEM18

'Throw (it) in there!'

However, there are also clitic forms of all three locative demonstratives (-pó, -kó, and -mó), which attach post-verbally. Note that in this case, the final vowel of the verb form remains unchanged, as the clitics do not have an initial vowel. 
(45)

a. Bíik-a=pó pa-cí-puna

put-FV=LC16 16-7-chair

'Put it there on the chair'

b. N-ka-y-a=kó maílo

SM1SG-FUT-go-FV=LC17 tomorrow

'I will go there tomorrow'

c. N-ka-fúm-a=mó

SM1SG-FUT-go_out-FV=LC18

'I will come out of there'

The locative clitics are always the last element of the verbal form, and they follow not only the final vowel, as in the examples in (45), but also the perfective suffix -ile (46) and the post-final imperative plural marker -ni (cf. Meeussen 1967: 111) which itself follows the final vowel (47):

(46) A-a-bíík-ílé='pó

maílo

SM1-PAST-put-PFV=LC16 yesterday

'S/he put it there yesterday'

(47) a. M-pél-é-ní

OM1SG-give-FV-PL

'Give (you all) me!' 
b. M-pél-é-ni=kó

OM1SG-give-FV-PL=LC17

'Give (you all) me, please'

Among the three Bemba locative clitics, it is only -kó which allows the use as substitutive applicative marker. The two remaining locative clitics -pó and -mó can be used with applicative verb forms, but retain their concrete, physical locative meaning:

(48)

a. Ábá-icé bá-ká-'sénd-él-a=kó

ím-fúmu ubu-ta

2-children SM2-FUT-carry-APPL-FV=LC17 9-chief 14-bow

'The children will carry the bow on behalf of the chief'

b. Ábá-icé bá-ká-'sénd-él-a=pó

ím-fúmu ubu-ta

2-children SM2-FUT-carry-APPL-FV=LC16 9-chief $\quad$ 14-bow

*Intd.: 'the children will carry the bow on behalf of the chief'

O.K. as 'the children are carrying the bow for the chief on there'

c. Ábá-icé bá-ká-'sénd-él-a=mó

ím-fúmu ubu-ta

2-children $\quad$ SM2-FUT-carry-APPL-FV=LC18 9-chief $\quad$ 14-bow

*Intd.: 'the children will carry the bow on behalf of the chief'

O.K. as: 'the children will carry the bow for the chief in there'

As (48a) shows, -kó is interpreted as a substitutive marker in the context of the applicative verb form, while the parallel locative clitics of class $16(48 \mathrm{~b})$ and 18 (48c) 
do not give rise to a substitutive reading, but encode concrete physical locations where the events are taking place.

However, as noted above, -kó retains its concrete, physical locative semantics, and can be used to express locative meaning provided there is a salient, relevant locative antecedent in the context, such as provided in (49a). The condition for a locative antecedent in the context may well be related to the original anaphoric demonstrative semantics of the Demonstrative 3 series from which the clitic -kó derives.

a. W-i-íngíl-a=kó

SM2SG-NEG-enter-FV=LC17 17-9.kitchen

'Don't enter the kitchen.'

b. Mutálé a-léé-'nj-ípík-íl-a=kó

Mutale SM1-PROG-OM1SG-cook-APPL-FV=LC17

'Mutale is cooking for (on behalf of) me', or 'Mutale is cooking for me there' ku-kicheni 
reading is the preferred reading unless contextual information supports the locative reading.

\subsection{Other grammaticalised uses of -kó}

In addition to encoding physical location and substitutive semantics (with applicative verb forms), -kó has a range of other grammaticalised functions, including as politeness marker, to emphasise the addressee, as a marker of surprise, and as partitive, verbal diminutive marker. These functions are discussed in this section.

In (47), repeated here as (50), -kó functions as an indirectness/politeness marker. This may be related to the locative sense by involving a notion of distance and hence respect.

(50) a. M-pél-é-ní

OM1SG-give-FV-PL

'Give (you all) me!'

b. M-pél-é-ni=kó

OM1SG-give-FV-PL=LC17

'Give (you all) me, please'

Furthermore, -kó can express emphatic meaning, placing emphasis on the addressee in examples like (51): 
(51) a. Mw-ípúsh-é-ni Kombé

OM1-ask-FV-PL Kombe

'Ask (you all) Kombe'

\section{b. Mw-ípúsh-é-ni=kó Kombé \\ OM1-ask-FV-PL=LC17 Kombe \\ 'Ask (you all) Kombe'}

In (51b) the clitic does not refer to a physical location, but rather it places emphasis on the addressee. Its use implies that the speaker has already asked without success, and is now asking the addressee to try, instead of the speaker or in the speaker's place. Although there is no applicative morphology involved, it is clear that this usage is related to substitutive applicatives. In both cases, the locative clitic establishes a relation between the subject and another agent (the applied object or the addressee) who performs an action which the addressee was supposed or obliged to perform, or, as in (51b), failed to perform successfully. An underlying semantic feature which ties the three uses - addressee-proximate demonstrative, addressee emphasis and substitutive - together is that the action is located at the addressee in the first two uses, and that one further step of abstraction allows locating the action at the beneficiary, applied object in substitutives. We will develop this idea further in section 7.

A possibly related use is seen in (52), where -kó is used to express the unusualness of an action; an earlier example of this was (36c) in section 5.1: 


\section{(52) Ábá-na bá-á-'ípík-a=kó ífy-umbu \\ 2-children SM2-PAST-cook-FV=LC17 8-potatoes \\ 'The children have (surprisingly) cooked potatoes'}

The use of -kó in (52) adds a nuance of surprise to the sentence, and implies that the children do not usually cook potatoes, and that their cooking is unusual. The interpretation is to some extent similar to substitutive interpretations, in that the agent performs an action which they do not usually perform, and which can therefore be assumed to be usually performed by someone else. The identity of the normal actor is not known, and there is no relation of substitution, but nevertheless, there is a sense of the agent performing an action which they do not normally perform. In terms of an abstract metaphor of location, this reading may involve the agent as performing an action at a place away from the deictic centre and at "another", unusual place. We will come back to this idea, too, in section 7.

A final use of the locative clitic is as a partitive, verbal diminutive marker giving rise to a complex set of interpretations (cf. Dierks 2010: 63 for a similar function of class 17 clitics in Bukusu):

\section{BanaPhiri bá-léé-i-ípík-a=kó in-kókó \\ BanaPhiri SM2-PROG-OM9-cook-FV=LC17 9-chicken}

'BanaPhiri is cooking the chicken a bit/partially'; 'BanaPhiri is cooking the chicken (out of all the other things which are also being cooked)'; 'BanaPhiri is cooking the chicken as a nice gesture/surprisingly' 
The first two interpretations result from the partitive meaning of -kó applied, in the first reading, to the verb phrase interpretation 'cooking (the) chicken', and in the second reading to a whole set of events of which the event described in (53) is only a part. The third reading of (53) is the "surprise" or "polite gesture" reading, described above. The partitive reading seems unrelated to substitutive or addressee-proximate readings, and may reflect a different grammaticalisation path.

The use of -kó in substitutive applicatives is thus only one use out of a range of readings which grammaticalised forms of the locative clitic can induce. While some uses are not clearly related to substitutive semantics, we have noted that addressee emphasis, surprise and possibly politeness can all be seen as sharing a similar meaning component as locating the action away from the speaker/agent. We will develop this idea in more detail as part of an analysis of substitutives in the next section.

\section{Abstract space and the grammaticalisation of substitutive meaning}

We have shown in the sections above that the substitutive interpretation of Bemba applicatives results from a combination of applicative morphology and the historic locative clitic -kó. In this section we are turning to a more detailed analysis of the construction and the underlying semantic and grammaticalisation processes involved in its interpretation. We are going to propose that this interpretation results from the interplay of the meaning of the two morphemes, and involves abstract and metaphorical uses of spatial relations. 
The use of spatial metaphors for substitutive meaning is in fact wide-spread and is found, for example, in idiomatic expressions in English, French and German. English expressions such as Can you go to the theater in my place?, He was speaking in her stead or In your shoes I wouldn't accept the offer (Ammer 2003) involve more or less transparent spatial metaphors. This is most clearly visible in in someone's place, but also in in someone's stead or instead of someone, which are based on the historic meaning of stead as 'place, site, town' (NSOED, s.v. stead). The more obviously idiomatic in someone's shoes uses shoes as a metaphor for where someone stands, and thus harnesses an underlying locational metaphor. Similar expressions exist in French (faire quelque chose à la place de quelqu'un, 'do something in the place of someone') and German (anstatt/anstelle einer/eines anderen, 'instead of someone else', in seiner/ihrer Statt 'in his/her stead'). In both languages, the meaning 'instead of' is expressed by spatial metaphors, involving French place 'place' and German Statt 'place' and Stelle 'place, spot'.

In contrast to English, French and German, Bemba does not employ an obvious nominal metaphorical form to express substitution. However, substitutive applicatives involve a (historical) locative clitic, and we propose that substitutive interpretations in Bemba involve a spatial metaphor similar to the one employed in nominal spatial metaphors. The metaphor takes concrete, physical location in space as source domain ('Place 1'), and transfers this to the target domain of an abstract space where agents perform actions and are embedded in social processes and constraints ('Place 2'):

(54) Metaphorical extension from physical to social space

Place $1=$ a physical space where someone is located; physical being 
Place $2=$ an abstract, imagined space where someone performs actions and fulfils roles, responsibilities, and obligations; abstract being of a socially constructed personality

Spatial metaphors like (54) are wide-spread and relevant for a range of different conceptualisations beyond the scope of the present paper (cf. Lakoff and Johnson 1980 and much subsequent work). However, we will show that (54) is also central for the explanation of Bemba substitutives.

We propose that Bemba substitutives are the result of a grammaticalisation process during which the locative marker -kó has become a marker of substitution when used with benefactive applicatives. In addition to the metaphorical extension from physical to social space, this process also involved the loss of the deictic meaning of the locative marker to express more contextual meanings (cf. Traugott 1989). Instead of the physical location of the addressee, which is the location relevant for the deictic reading of -kó as a demonstrative 3 (cf. section 6), the grammaticalised marker may take a textually or contextually established referent as the location where an action is taking place. In substitutives the more abstract meaning thus allows the reinterpretation of the deictic relation between speaker and hearer as the grammatically encoded relation between (referents of) subject and applied object, and the replacement of a physical entity in space by an abstract action located (i.e. performed) at the 'place of' the object. It is this transfer of spatial meaning from deictic reference to abstract meaning which also underlies the use of -kó as a marker of addresseeemphasis, surprise and politeness, discussed in section 6.2 above.

The interaction between benefactive applicative and substitutive marking with -kó involves a complex interplay between the abstract spatial meaning introduced by the 
applicative as directing the action of the verb towards the beneficiary (noted in section 4), and the spatial meaning introduced by -kó, which in conjunction with the spatial substitutive metaphor described above ("to do something in someone's place"), results in the substitutive interpretation. The interpretation of Bemba applicatives as substitutives is illustrated in (55):

(55) Substitutive interpretation of Bemba applicatives

1) Verbal action

\section{Mutálé alééípíka}

'Mutale is cooking'

2) Locative -kó: Verbal action is located/performed at physical Place 1 (the addressee's place)

\section{Mutálé alééípíka $=$ kó}

'Mutale is cooking there'

3) Benefactive: Verbal action directed to beneficiary

\section{Mutálé aléé'njípík-íl-a}

'Mutale is cooking for me'

4) a. Benefactive and locative -kó: The verbal action directed to the 
beneficiary is located at physical Place 1 , the addressee's place (= locative reading)

b. Benefactive and substitutive -kó: The verbal action directed to the beneficiary is located at social Place 2, the beneficiary's place (= substitutive reading)

\section{Mutálé aléé'njípík-íl-a=kó}

a. 'Mutale is cooking for me there'

b. 'Mutale is cooking instead of me'

There are three instances of abstract manipulation of space involved in the process in (55). In step 3, the benefactive applicative is analysed as directional - the action of Mutale's cooking is directed towards the beneficiary. The substitutive reading in step $4 \mathrm{~b}$ involves two instances of locative grammaticalisation. First, the deictic meaning of -kó is extended from physical space to abstract space, identifying the beneficiary's social space as location of the verbal action of Mutale's cooking. It is this aspect of the interpretation which requires an underlying benefactive reading for substitutives: The benefactive directs the action towards the beneficiary, which is therefore available as a (abstract) reference point for the locative. Second, the scenario of Mutale's cooking taking place at the place of the beneficiary is interpreted as substitution, employing the same metaphor employed in the European languages discussed earlier - by doing something in someone's (social) space, one does it instead of them. Thus since Mutale's cooking is taking place at the beneficiary's place, it is interpreted as Mutale's cooking instead of the beneficiary. As shown 
above, although the interpretation typically involves a situation in which the substituee was expected or obliged to perform the action, this is not necessarily the case, and the substitution relation can be construed differently in the right context. However, given the interaction between benefactive and substitutive interpretation in our analysis, it is expected that benefaction is part of substitutives. This is indeed confirmed, as we have shown above that substitutives are based on benefactives in terms of interpretation and structure. This was particularly clear from the interaction of substitution with malefactives and applicatives of movement predicates - in both cases, the substitutive reading only obtained with the applicatives re-interpreted as benefactive. We thus propose that the interpretation of substitutives results from the abstract spatial relations supplied by both the benefactive applicative and the grammaticalised locative marker -kó.

Under the analysis proposed here, an interesting parallel appears between substitutives and causatives. One effect of the semantics of substitutives is to establish a relation between the agent/subject and the beneficiary/applied object: Since the agent performs the action in the place of the beneficiary, the two are in the same place, and interpreted as being in a substitutive relation. In causatives, likewise, a relation is established between the subject and grammatical object, but with different semantic roles - in causatives the former is the causer of the action, the latter the causee and agent. While in causatives, the action is performed by the referent of the object, in substitutives it is performed by the referent of the subject. In both constructions, the respective other role is in a specific relation to the action: The causative subject as causer, the substitutive object as substituee.

This view of substitutives - as involving a relation between subject and applied object - is also interesting from the point of view of the typology of applicatives 
proposed in Pylkkänen (2008) and subsequent work, discussed in section 2. In this analysis, applicatives are divided into those which establish a relation between the event encoded by the verb and an individual encoded by the applied object, who, for example, benefits from the action (high applicatives), and those which establish a relation between two individuals (encoded by the applied object and a theme or locative object), for example in a possession relation (low applicatives). Against this background, substitutive applicatives constitute a third type, in which a relation is established between two individuals, but here encoded as subject and applied object. If this relation is taken as resulting from an underlying structural configuration, and subjects are taken as configurationally higher than predicates, substitutives could be thought of as "super-high" applicatives. However, we will leave it for a future occasion to investigate this possibility further.

We have shown in this section how substitutive meaning is constructed in Bemba substitutive applicatives. The meaning results from an interaction of the semantics of benefactive applicatives and abstract notions of space introduced by the grammaticalised substitutive and historic locative marker -kó. The construction involves different spatial metaphors, and it is thus not surprising that substitution in Bemba is expressed by a former locative marker. As part of the grammaticalisation of -kó, semantic notions of physical space are reconceptualised as more abstract spatial relations: The entity located at a place in the physical sense becomes an action performed in a place, the starting point of the spatial relation encoded by the demonstrative meaning of -kó is transferred from speaker to agent, and the end point from hearer to a textually or contextually constructed referent such as the beneficiary or the substituee. In addition, we have proposed that benefactive applicatives have an abstract locational sense of directing the action of the verb towards the beneficiary. 
Thus applicatives direct the action to the abstract space of the beneficiary, which can serve as the abstract end point of the grammaticalised locative marker -kó. With both the beneficiary and the agent located at the beneficiary's space, a final step of interpretation results in substitutive meaning. This final step involves a wide-spread metaphor which conceptualises being in someone's place as performing an action for them - to fulfil their role in the social space of their actions, plans and obligations. This analysis thus explains the morphology as well as the interpretative constraints of the construction.

Before drawing out further conclusions, we will turn to a final aspect of the construction, namely its place in wider comparative and typological contexts.

\section{Bemba substitutives in comparative and typological perspectives}

In this section we will locate Bemba substitutives in two wider contexts: A comparative one with respect to processes of locative grammaticalisation in Bantu, and a typological one with respect to the typology of substitutives.

As far as we know, Bemba is so far the only Bantu language for which formal substitutive marking has been described. However, the grammaticalisation of locative clitics to express more grammatical meaning is wide-spread, as we will show in this section by discussing three examples of locative grammaticalisation in Bantu.

From a wider typological perspective, different strategies of substitutive marking can be distinguished, and we will show how Bemba substitutives relate to wider typological patterns of the marking of applicatives and substitutives in the second part of this section. 


\subsection{Related locative grammaticalisation processes in Bantu}

Locatives, and in particular class 17 locatives, are part of a range of grammaticalisation processes in different Bantu languages. While in Bemba, the class 17 locative marker -kó has developed into a substitutive marker, locative clitics have assumed different functions in other languages. In this section we will discuss three examples of this: locative applicatives, marking of syntactic subordination, and negation.

The grammaticalised form of locative marking most similar to Bemba substitutive applicatives is the use of a locative clitic in what is sometimes analysed as a locative applicative marker. This is found most often in north-east Bantu languages such as Kinyarwanda (Kimenyi 1995, Zeller and Ngoboka 2006) or Bukusu, at least in the variety described in Peterson (2007: 12-14), although not in the one described in Dierks (2010: 62-68). Like Bemba, Kinyarwanda and (some varieties of) Bukusu have an applicative marker related to the common Bantu applicative marker -IL-, which can express a range of applicative constructions. In addition, locative applicatives are expressed by a locative clitic such as class 16 -ho in Kinyarwanda, or class 17 -xo and class 18 -mo in Bukusu:

\footnotetext{
Umu-juura $\quad$-a-tee-ye $=$ ho in-zu ama-buye [Rwanda] 1-thief SM1-PAST-throw-ASP=APPL 9-house 6-stones

'The thief threw the stones on the house' (Zeller \& Ngoboka 2006: 101)
} 
In contrast to Bemba substitutive applicatives, in these locative applicatives, the locative clitic is found after a non-extended verb form, and is thus the only morphological marker showing that the construction is an applicative construction. This can be seen as evidence that the grammaticalisation process has progressed further than in the case of substitutive applicatives, where the locative marker has not developed into a full applicative marker. On the other hand, the semantics of the locative applicative construction appears to be more transparent. The locative clitics are used to introduce locative arguments, and so the grammaticalised form is semantically closer to its source than in the case of the substitutive -kó in Bemba, which encodes more abstract locative semantics. Nevertheless, the fact that very similar locative clitics are used in the same construction type is worth exploring further.

A second example of the grammaticalisation of locatives is found in the marking of subordinated clauses in southern Bantu languages such as Northern Sotho, Swati, Venda, and Zulu (e.g. Poulos 1985, Visser 1995, Zeller 2004), as the following examples from Swati show:

a. Um-fati tin-tfombi la-iti-m-elekelel-a=ko

1-woman 10-girl REL-SM10-OM1-help-FV=REL

'The woman whom the girls help ...' (Marten et al. 2007: 273)

\title{
b. Ngi-nats-a=ko
}

\author{
SM1SG-drink-FV=LC17
}

'(while) I drink’ (Ziervogel \& Mabuza 1976: 111) 
In (57a), the locative clitic at the end of the verb form marks a relative clause, and in (57b) a participial clause. In these cases, locative marking has typically spread beyond clearly locative contexts and is used as a, sometimes optional, marker of clause subordination in general. This is part of a wider tendency in southern Bantu languages to use class 17 agreement forms in default and impersonal contexts (Buell 2012, Marten 2010), and this presents, in terms of details, a different situation from the one found in Bemba substitutive marking, with less obvious similarity than the first example.

The final example we present here is the case of (historic) locative markers being used to mark clausal negation, for example in Kikongo:

(58) Nzumba ka-lemb-a

ma-dya ko

[Kongo]

Nzumba NEG-cook-PAST 6-meal NEG

'Nzumba did not cook the meal' (Mbiavanga 2008: 148)

The marking of negation, like the marking of subordination, is on the face of it a considerable distance away from marking substitutive applicatives, and it would require a more thorough analysis to ascertain any relations between the different contexts.

The examples presented here are illustrative rather than exhaustive, and further grammaticalised forms of locatives can be found in different Bantu languages. However, the few examples here show that the grammaticalisation process underlying substitutive marking in Bemba, taking a class 17 anaphoric locative clitic as starting point, is not an isolated phenomenon. While so far no other Bantu languages have been described in which a locative is used to mark substitutive applicatives, the 
grammaticalisation of locatives is very common, and locatives take part in a wide range of grammaticalisation processes. Evidence from Bemba thus adds to the picture of the possible paths locatives can take, and contributes to a better understanding of these processes. ${ }^{10}$

\subsection{Typology of benefactives}

A final relevant point of the analysis of Bemba substitutives is the position of the construction, and in particular the morphological marking with both the applicative maker -il and the former locative marker -kó, in the context of the typology of benefactives developed by Kittilä (2005) and briefly discussed in section 3 above. Bemba is part of the group of languages in which plain and recipient benefactives are marked identically, while substitutive benefactives are marked differently. It is, in Kittilä's (2005) terms, a recipient-prominent language, as both recipients and plain benefactives are marked alike. With respect to the morphological marking of benefactive constructions in different languages, a wide range of patterns is found, from languages where all three types of benefactives - recipient, plain and substitutive - are marked differently, to those where only one marker is used, to those were two different markers are used, with one of them marking two types. However, there are also languages where, like in Bemba, benefactives are doubly marked, by both a general applicative marker and a specific benefactive/substitutive marker. For

\footnotetext{
${ }^{10}$ In Riedel and Marten (2012) it is proposed that the versatility of locatives with respect to the grammaticalisation processes in which they are found may in part result from the often ambiguous status of locatives between argument and adjunct.
} 
example, this is the case in Southeastern Tepehuan, an Uto-Aztecan language (Willett 1991: 76-77, 182-183; quoted from Kittilä 2005: 280), where plain and recipient benefactives are marked by the verbal suffix -dya, while substitutive benefactives are marked by -dya and the addition of the substitutive suffix -xi:

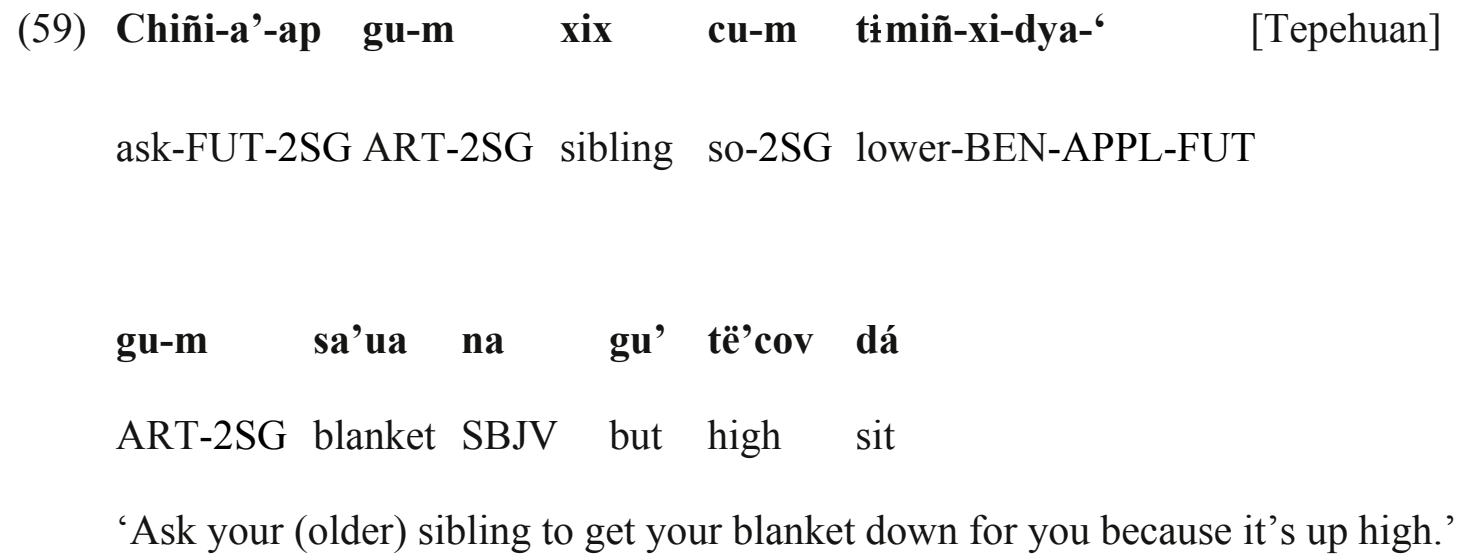

The example is quite similar to Bemba in that two verbal markers are used: an applicative marker and an additional marker for substitutive benefactives. Similar to the Tepehuan example, Tamil benefactives involve double marking. Recipient benefactive objects are marked by a dative suffix, and objects of plain and substitutive benefactives are marked in addition by the benefactive suffix -aaka (Lehmann et al. 2000: 70, 76, 93, quoted from Kittilä 2005: 281-2):

(60) Rani pillai-akk-aaka muti-yai vari-vittaal [Tamil]

Rani child-DAT-BEN hair-ACC comb-comp.3SG.F

'Rani has combed the child's hair (for him/her).' 
However, the Tamil markers are nominal suffixes, rather than verbal markers as in Bemba and Tepehuan. ${ }^{11}$

The existence of other instances of double marking of substitutive benefactives, and in particular the use of a specific benefactive/substitutive marker in addition to a more generic benefactive/applicative marker might provide further relevant evidence for the proposal that substitution is closely linked to, and presupposes benefaction. This idea is further supported by the fact that the potential alternative case, in which substitutives would be marked once, and an additional marker would be used for recipient benefactives appears to be unattested or in any case rare (cf. Marten 2011). The typological context thus raises questions about the wider applicability of the proposal for Bemba developed here, that substitutive meaning is composed of direction (contributed by the applicative marker) and abstract location (contributed by the historic locative marker), and hence more likely to be morphologically encoded by two morphemes. More detailed studies of substitutive constructions will show if this compositional analysis finds confirmation from other languages.

${ }^{11}$ Cases of marking benefactives both on the noun and on the verb (as in Japanese and Korean) might be included here as well. A further well-known example of double marking of substitutives is the verbal marking in Lakhota, where a verbal prefix kicimarks substitutives which might be composed of two morphemes; however, the case is not fully clear (cf. Boas and Deloria 1941, van Valin and LaPolla 1997: 384, Zúñiga 2012: 342-6). 


\section{Conclusions}

The preceding discussion has shown how in Bemba, benefactive applicative semantics and abstract locative semantics interact in the expression of substitutive applicatives. These are consequently marked both by applicative morphology and the class 17 post-verbal locative clitic -kó. Substitutive applicatives are based on benefactive applicatives, and behave like these syntactically, i.e. with respect to the status of the applied object and the asymmetry of the two objects of the construction. While the locative clitic -kó can be combined with other types of applicatives, such as locative or instrumental applicatives, as well as with non-applicative verb forms, the specific substitutive interpretation only arises when the locative clitic is combined with benefactive applicatives. This is particularly clear from the interaction between applicatives of movement predicates. There, applicatives induce a directional reading, but when combined with a locative clitic and a suitable substituee argument, this reading is no longer available, and only a substitutive interpretation is possible.

The particular semantics of the locative clitic in our analysis results from a metaphorical extension of the meaning of the locative clitic from denoting physical space (and originally location near to the addressee) to abstract, socially constructed space. Due to this abstract meaning, in combination with benefactive semantics, typical substitutive readings involve the abstract space of the beneficiary, in which the agent performs the action of the verb. Through a common metaphorical extension from being in someone's place to performing an action for or instead of them, a substitutive reading results. Being marked by applicative and locative morphology, the construction thus formally reflects transparently the two meaning components which give rise to the particular interpretation associated with substitutive 
applicatives. Since both meaning components of the construction are abstract representations, the lexical meaning of substitutive applicatives is underdetermined and the eventual interpretation of the form relies on further information pragmatically supplied by the context, or encoded overtly in the clause.

We have shown that there are a number of aspects of Bemba substitutives which are part of wider cross-linguistic processes and patterns. For example, the semantic aspects of the grammaticalisation process we have proposed are part of much more wide-spread processes of the metaphorical conceptualisation of abstract space in terms of physical space, and the more specific metaphorical expression of substitution as performing an action in someone's place. In terms of the formal marking of Bemba substitutives, we have shown that post-verbal locative clitics play a part in a range of grammaticalisation processes in Bantu, and are used, for example, for the marking of locative applicatives, relatives and negation. Finally, we have shown that in terms of morphological marking Bemba substitutives are similar to a number of languages in which substitutive applicatives are also marked by two distinct morphemes.

The analysis proposed here thus also raises further questions about the analysis of substitutive applicatives in other (Bantu and non-Bantu) languages, as well as about the grammaticalisation of space and location in different construction types, and about the morphosyntactic marking of substitutives cross-linguistically.

\section{References}

Abdulaziz, Mohammed 1996. Transitivity in Swahili. Cologne: Rüdiger Köppe Verlag. 
Abdulla, Muhammed Said 1960. Mzimu wa watu wa kale. Nairobi: Kenya Literature Bureau.

Abe, Maya 2011. Applicative and double object constructions in Mbugu/Ma'a. Paper presented at the 4th International Conference on Bantu Grammar, Berlin, April 2011.

Alsina, Alex \& Sam A. Mchombo 1993. Object asymmetries and the Chichewa applicative construction. In Sam A. Mchombo (ed.), Theoretical aspects of Bantu grammar, 17-45. Stanford, CA: CSLI.

Ammer, Christine 2003. The American heritage dictionary of idioms. Boston, MA: Houghton Miffin Harcourt. Available online at http://idioms.yourdictionary.com/, last accessed 21 May 2012.

Baker, Mark 1989. Object sharing and projection in serial verb constructions. Linguistic Inquiry 20. 513-553.

Bearth, Thomas 2003. Syntax. In Derek Nurse \& Gérard Philippson (eds), The Bantu languages, 121-142. London: Routledge.

Boas, Franz and Ella Deloria 1941. Dakota grammar (Memoirs of the National Academy of Science, vol. 23, $2^{\text {nd }}$ memoir). Washington, D.C.: United States Government Printing Office.

Bresnan, Joan and Jonni Kanerva 1989. Locative inversion in Chichewa: a case of factorization in grammar. Linguistic Inquiry 20. 1-50.

Bresnan, Joan and Lioba Moshi 1990. Object asymmetries in comparative Bantu syntax. Linguistic Inquiry 21. 147-185. Repr. in Sam A. Mchombo (ed.) 2003, Theoretical aspects of Bantu grammar, 47-91. Stanford, CA: CSLI.

Buell, Leston 2012. Class 17 as non-locative noun class in Zulu. Journal of African Languages and Linguistics 33. 1-35. 
Cammenga, Jelle 2002. Phonology and morphology of Ekegusii: A Bantu language of Kenya. Cologne: Rüdiger Köppe Verlag.

Cann, Ronnie \& Patricia Mabugu 2006. Constructional polysemy: the applicative construction in ChiShona. Metalinguistica 19. 1-26.

Dammann, Ernst 1961. Das Applikativum in den Bantusprachen. Zeitschrift der deutschen morgenländischen Gesellschaft 111 (NF 36). 160-9.

Dierks, Michael 2010. Agreement with subjects in Lubukusu. PhD dissertation, Georgetown University.

Doke, Clement Martyn 1931. Textbook of Zulu grammar. $2^{\text {nd }}$ ed. London: Longman, Green \& Co.

Good, Jeff 2005. Reconstructing morpheme order in Bantu: The case of causativization and applicativization. Diachronica 22. 3-57.

Grimshaw, Jane 1992. Argument structure. Cambridge, MA: MIT Press.

Harford, Carolyn 1993. The applicative in Shona and lexical mapping theory. In Sam A. Mchombo (ed.), Theoretical aspects of Bantu grammar, 93-111. Stanford, CA: CSLI.

Henderson, Brent 2011. African languages and syntactic theory: Impacts and directions. In Eyamba G. Bokamba et al. (eds), Selected proceedings of the 40th annual conference on African linguistics, 15-25. Somerville, MA: Cascadilla Proceedings Project.

Hoch, E. n.d. A Bemba grammar with exercises. Chinsali, Zambia: Ilondola Language Centre.

Ittman, Johannes 1939. Grammatik des Duala (Kamerun). Berlin.

Jackendoff, Ray 1990. Semantic structures. Cambridge, MA: MIT Press. 
Jeong, Youngmi 2006. The landscape of applicatives. PhD dissertation, University of Maryland, College Park.

Kibao, Salim A. 1975. Matatu ya thamani. Nairobi: Heinemann Educational Books. Kimenyi, Alexandre 1995. Kinyarwanda applicatives revisited. Paper read at the 8th Niger-Congo syntax and semantics workshop on the applicative architectures. Boston University, October 25-26, 1995. Available on-line at: http://kimenyi.com/kinyarwanda-applicatives-revisited.php

Kittilä, Seppo 2005. Recipient-prominence vs. beneficiary-prominence. Linguistic Typology 9. 269-297.

Kula, Nancy C. \& Lutz Marten 2010. Argument structure and agency in Bemba passives. In Karsten Legère \& Christina Thornell (eds), Bantu languages: analyses, description and theory (East African Languages and Dialects, 20), 115-130. Cologne: Rüdiger Köppe Verlag.

Lakoff, George \& Mark Johnson 1980. Metaphors we live by. Chicago: Chicago University Press.

Lehmann, Christian, Yong-Min Shin, \& Elisabeth Verhoeven 2000. Direkte und indirekte Partizipation: Zur Typologie der sprachlichen Repräsentation konzeptueller Relationen. Munich: Lincom Europa.

Mann, Michael 1977. An outline of Bemba grammar. In Michael Mann, Mubanga E. Kashoki \& J. L. Wright (eds), Language in Zambia: Grammatical sketches. Volume 1: Bemba and Kaonde, 6-61. Lusaka: Institute for African Studies, University of Zambia.

Margetts, Anna \& Peter K. Austin 2007. Three-participant events in the languages of the world: towards a cross-linguistic typology. Linguistics 45. 393-451. 
Marten, Lutz 2002. At the syntax-pragmatics interface: Verbal underspecification and concept formation in Dynamic Syntax. Oxford: Oxford University Press.

Marten, Lutz 2003. The dynamics of Bantu applied verbs: an analysis at the syntaxpragmatics interface. In Kézié K. Lébikaza (ed.), Actes du 3e Congrès Mondial de Linguistique Africaine Lomé 2000, 207-221. Cologne: Rüdiger Köppe Verlag.

Marten, Lutz 2010. The great siSwati locative shift. In Anne Breitbarth, Christopher Lucas, Sheila Watts \& David Willis (eds), Continuity and change in grammar, 249-267. Amsterdam: Benjamins.

Marten, Lutz 2011. Bemba benefactive constructions in the typology of applicatives. In Peter Austin, Oliver Bond, Lutz Marten \& David Nathan (eds), Proceedings of the $3^{\text {rd }}$ conference on language description and theory, 183-192. London: SOAS.

Marten, Lutz \& Nancy C. Kula 2012. Object marking and morphosyntactic variation in Bantu. Southern African Linguistics and Applied Language Studies 30.

Marten, Lutz, Nancy C. Kula \& Nhlanhla Thwala 2007. Parameters of morphosyntactic variation in Bantu. Transactions of the Philological Society 105. 253-338.

Mbiavanga, Fernando 2008. An analysis of verbal affixes in Kikongo with special reference to form and function. MA dissertation, University of South Africa.

McGinnis, Martha 2001. Variation in the phase structure of applicatives. Linguistic Variation Yearbook 1. 105-146.

Mchombo, Sam A. 2004. The syntax of Chichewa. Cambridge: Cambridge University Press. 
Mchombo, Sam A. \& Gregória Firmino 1999. Double object constructions in Chichewa and Gitonga: A comparative analysis. Linguistic Analysis 29. 214233.

Meeussen, Achille E. 1967. Bantu grammatical reconstruction. Africana Linguistica 3. $79-121$.

Moshi, Lioba 1998. Word order in multiple object constructions in KiVunjo-Chaga. Journal of African Languages and Linguistics 19. 137-152.

Ngonyani, Deo \& Peter Githinji 2006. The asymmetric nature of Bantu applicative constructions. Lingua 116. 31-63.

NSOED, The New Shorter Oxford English Dictionary 1993. 4th ed.. Ed. by Lesley Brown. Oxford: Clarendon Press.

Peterson, David A. 2007. Applicative constructions. Oxford: Oxford University Press.

Petzell, Malin 2008. The Kagulu language of Tanzania. Cologne: Rüdiger Köppe Verlag.

Poulos, G. 1985. Instances of semantic bleaching in South-Eastern Bantu. In Gerrit Dimmendaal (ed.), Current approaches to African linguistics (Vol. 3), 281-296. Dordrecht: Foris.

Pylkkänen, Liina 2008. Introducing arguments (Linguistic Inquiry Monographs Series). Cambridge, MA: MIT Press.

Riedel, Kristina \& Lutz Marten 2012. Locative object marking and the argumentadjunct distinction. Southern African Linguistics and Applied Language Studies 30.

Robertson, William Govan 1904. An introductory handbook of the language of the Bemba people (Awemba). London: London Missionary Society. 
Sadler, Wesley 1964. Untangled Bemba: A language of Northern Rhodesia, Central Africa. Kitwe: The United Church of Central Africa in Rhodesia.

Sambeek, J. van 1955. A Bemba grammar. Cape Town: Longmans.

Schadeberg, Thilo C. 2003. Derivation. In Derek Nurse \& Gérard Philippson (eds.), The Bantu languages, 71-89. London: Routledge.

Seidel, Frank 2008. A grammar of Yeyi. Cologne: Rüdiger Köppe Verlag.

Simango, Silvester Ron 2007. Enlarged arguments in Bantu: Evidence from Chichewa. Lingua 117. 928-949.

Sims, George W. 1959. An elementary grammar of Cibemba. Fort Roseberry: Mansa Mission.

Spellenberg, Friedrich 1922. Die Sprache der Bo oder Bankon in Kamerun. Berlin. Traugott, Elizabeth Closs 1989. On the rise of epistemic meaning in English: an example of subjectification in semantic change. Language 65. 31-55.

Van Valin, Robert D. \& Randy J. LaPolla 1997. Syntax: Structure, meaning and function. Cambridge: Cambridge University Press.

Vansina, Jan 1959. Esquisse de Grammaire Bushong. Tervuren: Musée royal du Congo belge.

Visser, Marianna 1995. A typology of relative clause constructions in Xhosa and Venda. Proceedings of the eight international conference of ALASA, 1995. $61-62$.

Wald, Benji 1998. Issues in the north/south syntactic split of East Bantu. In Ian Maddieson \& Thomas J. Hinnebusch (eds), Language history and linguistic description in Africa, 95-106. Trenton, N.J.: Africa World Press.

Willett, Thomas L. 1991. A reference grammar of Southeastern Tepehuan. Dallas: Summer Institute of Linguistics. 
Zeller, Jochen 2004. Relative clause formation in the Bantu languages of South Africa. Southern African Linguistics and Applied Language Studies 22. 75-93.

Zeller, Jochen \& Paul Ngoboka 2006. Kinyarwanda locative applicatives and the Minimal Link Condition. Southern African Linguistics and Applied Language Studies 24. 101-124.

Ziervogel, Dirk \& Enos John Mabuza 1976. A grammar of the Swati language. Pretoria: J.L. van Schaik.

Zúñiga, Fernando 2010. The grammar of benefaction: A crosslinguistic study. Habilitation dissertation, University of Zürich.

Zúñiga, Fernando \& Seppo Kittilä (eds) 2010. Benefactives and malefactives: Typological perspectives and case studies. Amsterdam: Benjamins. 